\title{
Performance of Soybean [Glycine max (L.) Merrill] Cultivars under Irrigated and Rainfed Conditions
}

József Csajbók ${ }^{1}$ Erika Tünde Kutasy, Anteneh Agezew Melash, István Csaba Virág, Éva Babett Ábrahám

10.18805/LRF-666

\begin{abstract}
Background: This study aimed to evaluate the performance of selected soybean varieties under irrigated and rainfed conditions. Methods: A split-plot field experiment was conducted with 11 soybean cultivars on chernozem soil under irrigated and non-irrigated conditions during 2017-2019. There were four replications. The LAI, NDVI values, plant height, number of nodes, the height of the lowest pod, seed yield, protein yield, moisture, protein and oil content of the seeds were observed.

Result: In the 3 years there were significant differences in LAI among the varieties, Isidor (2017: 9.2, 2018: $\left.15.0 \mathrm{~m}^{2} \mathrm{~m}^{-2}\right)$ and Bólyi 612 (2019: $9.5 \mathrm{~m}^{2} \mathrm{~m}^{-2}$ ) showed the highest LAI. Irrigation significantly increased the LAI (24.1\%) and height of the soybean (9.83\%) on average of the years. NDVI values were not affected by the irrigation in this experiment, not even in the droughty 2017 year. Seed yield was not increased by the irrigation in 2017 and 2018, the difference was significant only in 2019. Irrigation increased the protein content by $3.9 \%$. There were significant differences in the protein content and protein yield of the genotypes in all three years. On average of the 3 years, Isidor produced the highest protein yield $\left(1659.3 \mathrm{~kg} \mathrm{ha}^{-1}\right)$.

Key words: Irrigation, LAI, NDVI, Nodes, Soybean, Yield.
\end{abstract}

\section{INTRODUCTION}

Soybean [Glycine max (L.) Merill] is an important leguminous crop cultivated throughout the world with many diversified uses (Zhao et al. 2017). It is rich in vitamins and biologically active ingredients and on average contains $40-42 \%$ protein and $18-22 \%$ oil (Shi et al. 2010), 35\% carbohydrates and $5 \%$ minerals (Wilson, 2004). As a legume crop, soybean plays an irreplaceable role in the farming system through establishing symbiotic relations with nitrogen-fixing bacteria. The symbiotic association for nitrogen fixation is significantly dictated by abiotic factors including drought stress (Sinclair et al. 2007; Wu et al. 2020; Jaybhay et al. 2021). This can reduce the supply of nitrogen for seed protein accumulation (Kunert and Vorster, 2020), as nitrogen is the main building block of proteins.

Despite the agronomic and environmental advantages, the production and yield stability of soybean is also constrained by drought stress (Du et al. 2020). The major effect of drought is the reduction in photosynthesis, which arises from a decrease in chlorophyll content, relative water content (Dong et al. 2019), normalized difference vegetation index and leaf area index (Basal and Szabó, 2020).

In soybean, drought stress can occur at any growing stage. However, concerning the seed yield, the stage at which drought occurs is critical; its effects are more pronounced if water stress takes place at generative stages (Jha et al. 2018). These stages are elucidated more sensitivity and cause substantial quantity and quality loss (Licht et al. 2013). Soybean requires a sufficient amount of water during the growing period, with the fact that the drought-tolerant level is fundamentally influenced by the yielding potential of the varieties (Aydinsakir, 2018). It has
Institute of Crop Sciences, Faculty of Agricultural and Food Sciences and Environmental Management, University of Debrecen, USA.

1UD Institute of Crop Sciencies, Böszörményi str. 138, H-4032 Debrecen, Hungary.

Corresponding Author: József Csajbók, UD Institute of Crop Sciencies, Böszörményi str. 138, H-4032 Debrecen, Hungary. Email: csj@agr.unideb.hu

How to cite this article: Csajbók, J., Kutasy, E.T. Melash, A.A., Virág, I.C. and Ábrahám, É.B. (2022). Performance of Soybean [Glycine max (L.) Merrill] Cultivars under Irrigated and Rainfed Conditions. Legume Research. DOI: 10.18805/LRF-666.

Submitted: 08-11-2021 Accepted: 22-01-2022 Online: 14-02-2022

been observed that under drought stress conditions, high yielder soybean varieties were able to encounter the deficit water (Buezo et al. 2019; Oral et al. 2021).

Tremendous efforts have been placed as a drought adaptation strategy, with the primary aim of improving seed yield, protein and oil contents in soybean. The agro-technical measures such as selection of suitable soybean varieties and application of irrigation water during crop growth stages are widely accepted strategies to improve yield, protein and oil contents (Bellaloui and Mengistu, 2008; Revathi et al. 2021). Innovative irrigation practice has been reported as a practical solution and its application at the flowering stage can increase grain yield and water use efficiency of crops by improving root distribution in the subsoil layers (Jha et al. 2018; He et al. 2020). Water requirement of soybean increases with plant development, peaking at the flowering stage up to the grain-filling period and is reduced thereafter 
(Souza et al. 2013). Hence, irrigation water applied at the later stage would improve leaf area index, total dry-matter production, seed yield and ultimately increase profit margins compared to rainfed conditions (Montoya et al. 2017).

Irrigation water application during the reproductive stage has been proved to improve soybean yield by $12-33 \%$, compared with rainfed production (Wu et al. 2020). However, substantial genetic variation was observed in yield and seed protein content in response to supplemental irrigation (Bellaloui and Mengistu, 2008; Garcia y Garcia et al. 2010). The significance of soybean production is increasing in Hungary in a great part due to the growing demand for animal husbandry and the food industry. In parallel to this, the occurrence of droughty periods is more frequent, due to climate change. This study aimed to evaluate the performance of 11 soybean varieties and their response to irrigation under Central European conditions.

\section{MATERIALS AND METHODS}

The research was conducted in 2017-2019 at the Látókép Crop Production Experiment Station of the University of Debrecen, Debrecen, Hungary. The coordinates of the experimental site were $47^{\circ} 33^{\prime} 42^{\prime \prime} \mathrm{N} ; 21^{\circ} 27^{\prime} 02{ }^{\prime \prime} \mathrm{E}$.

The meteorological data of the experimental years proved that the rainfall of pre-vegetation periods (from October to March) was slightly $(+20.9 \mathrm{~mm})$ and much $(+131.7 \mathrm{~mm})$ higher, compared with the 30 -years average $(220.2 \mathrm{~mm})$ in 2017 and 2018, respectively. In 2019 the precipitation of the pre-vegetation was lower than the average $(-55 \mathrm{~mm})$. The water supply state in the vegetation period (April-September) was more favourable in 2019 compared to the 2018 and 2017 years (Fig 1).

The rainfall in the vegetation period was $355.4 \mathrm{~mm}$ in 2017, $323.4 \mathrm{~mm}$ in 2018 and $363 \mathrm{~mm}$ in 2019.

The site has Calcic Endofluvic Chernozem (Endosceletic) (WRB, 2014). The humus layer of the research field is around $80 \mathrm{~cm}$ deep. The humus content $(\mathrm{Hu} \%)$ of the upper layer is $2.7-2.8 \%$. The $\mathrm{pH}$ of the upper soil layers is almost neutral $\left(\mathrm{pH}_{\mathrm{KCl}}=6.46-6.6\right)$. The soil has an average phosphorus supply (AL-soluble $\mathrm{P}_{2} \mathrm{O}_{5} 133 \mathrm{mg}$ $\mathrm{kg}^{-1}$ ) and an average-good potassium supply (AL-soluble $\mathrm{K}_{2} \mathrm{O} 240 \mathrm{mg} \mathrm{kg}^{-1}$ ).

The experiment was laid out in a split-plot design with four replications. One plot was $27 \mathrm{~m}^{2}$, the total area of the experiment was $2376 \mathrm{~m}^{2}$. Sowing was done on 26 April in 2017, on 23 April in 2018 and on 24 April in 2019 using 95 $\mathrm{kg}$ per ha seed rate. The forecrop was maize in 2017 and winter wheat in 2018 and 2019. In the experiment $70 \mathrm{~kg} \mathrm{ha}^{-1}$ $\mathrm{N}$ fertilizer was applied.

We used 11 soybean varieties (Table 1) and two irrigation levels: non-irrigated (rainfed) and irrigated. In the irrigated plots $80 \mathrm{~mm}$ water was added in 2017 and 2018, in 2019 the rainfall was higher and $50 \mathrm{~mm}$ water was applied. Normalized difference vegetation index (NDVI) was measured 5 times in a year with a Trimble GreenSeeker handheld crop sensor (Trimble Inc., USA). Leaf area index (LAI) was measured using Delta-T SunScan SS1 portable

Table 1: The varieties and their maturity groups (All cultivars are GMO-free).

\begin{tabular}{lcr}
\hline Variety & Maturity group & \multicolumn{1}{c}{ Breeder } \\
\hline Ananda & $0 / I$ & Saaten Union, Germany \\
Bóbita & $1 / I I$ & Bonafarm, Hungary \\
Boglár & 00 & Bonafarm, Hungary \\
Bokréta & 00 & Bonafarm, Hungary \\
Bólyi 612 & 0 & Bonafarm, Hungary \\
Coraline & $00 / 0$ & Saaten Union, Germany \\
ES Mentor & 0 & Euralis, France \\
ES Navigator & 000 & Euralis, France \\
ES Pallador & $\mathrm{I}$ & Euralis, France \\
Isidor & $\mathrm{I}$ & Euralis, France \\
Pannónia kincse & $\mathrm{I}$ & Cereal Research Institute, Hungary \\
\hline
\end{tabular}

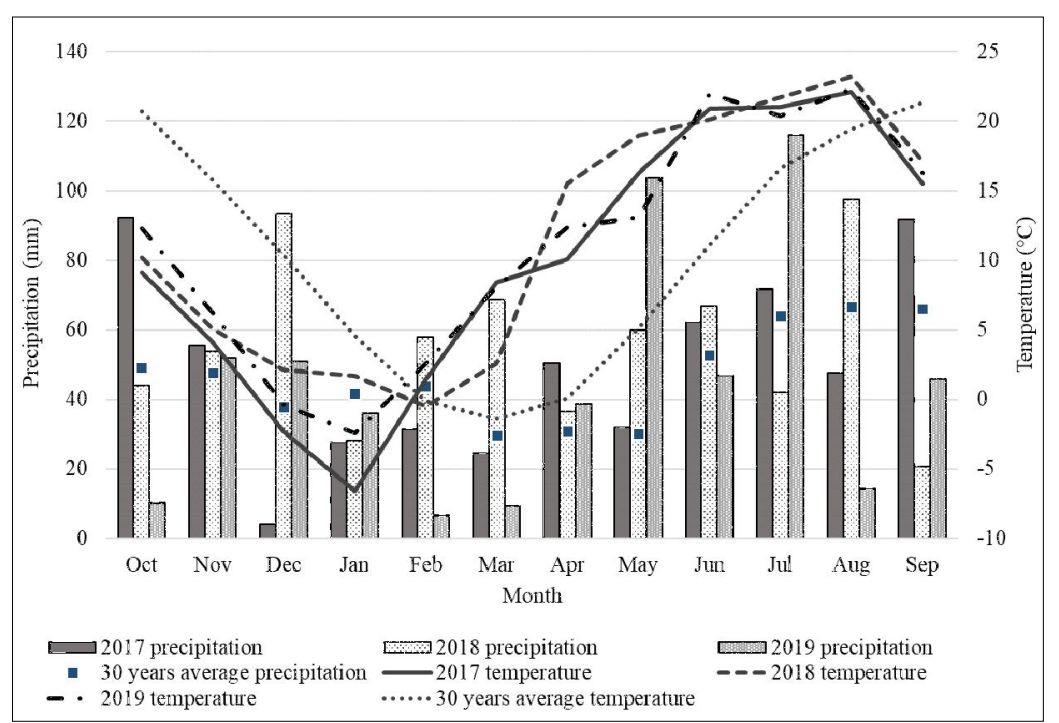

Fig 1: Weather data of the experimental site (2017-2019). 
plant canopy analyser system (Delta-T Devices Ltd., UK). Plant height, number of nodes, number of pods were observed in five plants per plot. The moisture, protein and oil content were measured using Pfeuffer Granolyser NIR (Pfeuffer, Germany). The protein yield was calculated from the grain yield and protein content.

The data were evaluated using IBM-SPSS 22.0 (IBM Corp. Chicago, USA) statistical software package. GLM model to compare the means, with options of descriptive statistics and LSD post hoc tests and Pearson correlation analysis (2-tailed) to test the linear connections were used.

\section{RESULTS AND DISCUSSION}

Due to the good soil conditions and good production practices, soybean genotypes produced large leaf area and the maximum $\left(9.23 \mathrm{~m}^{2} \mathrm{~m}^{-2}\right)$ was recorded at Isidor genotype in 2017, followed by at Isidor $\left(15.03 \mathrm{~m}^{2} \mathrm{~m}^{-2}\right)$ in 2018 and Bólyi $612\left(9.48 \mathrm{~m}^{2} \mathrm{~m}^{-2}\right)$ in 2019 . We found significant differences $(p<0.05)$ in LAI between the two irrigation treatments in 2017, 2018 and 2019 in all the five measurement times, except the first measurement in 2018 (Fig 2). Drought stress reduced the vegetative growth in 2017 and 2018 and the irrigated plants developed a larger leaf area (Fig 3-5).

On average of the genotypes, the irrigation treatment resulted in $22.11,32.35$ and $17.77 \%$ higher LAl of soybeans in 2017, 2018 and 2019, respectively. Similar observations were made by Basal and Szabó (2020).

We found that the irrigation significantly increased the height of the soybean plants in all the three years (by $9.83 \%$

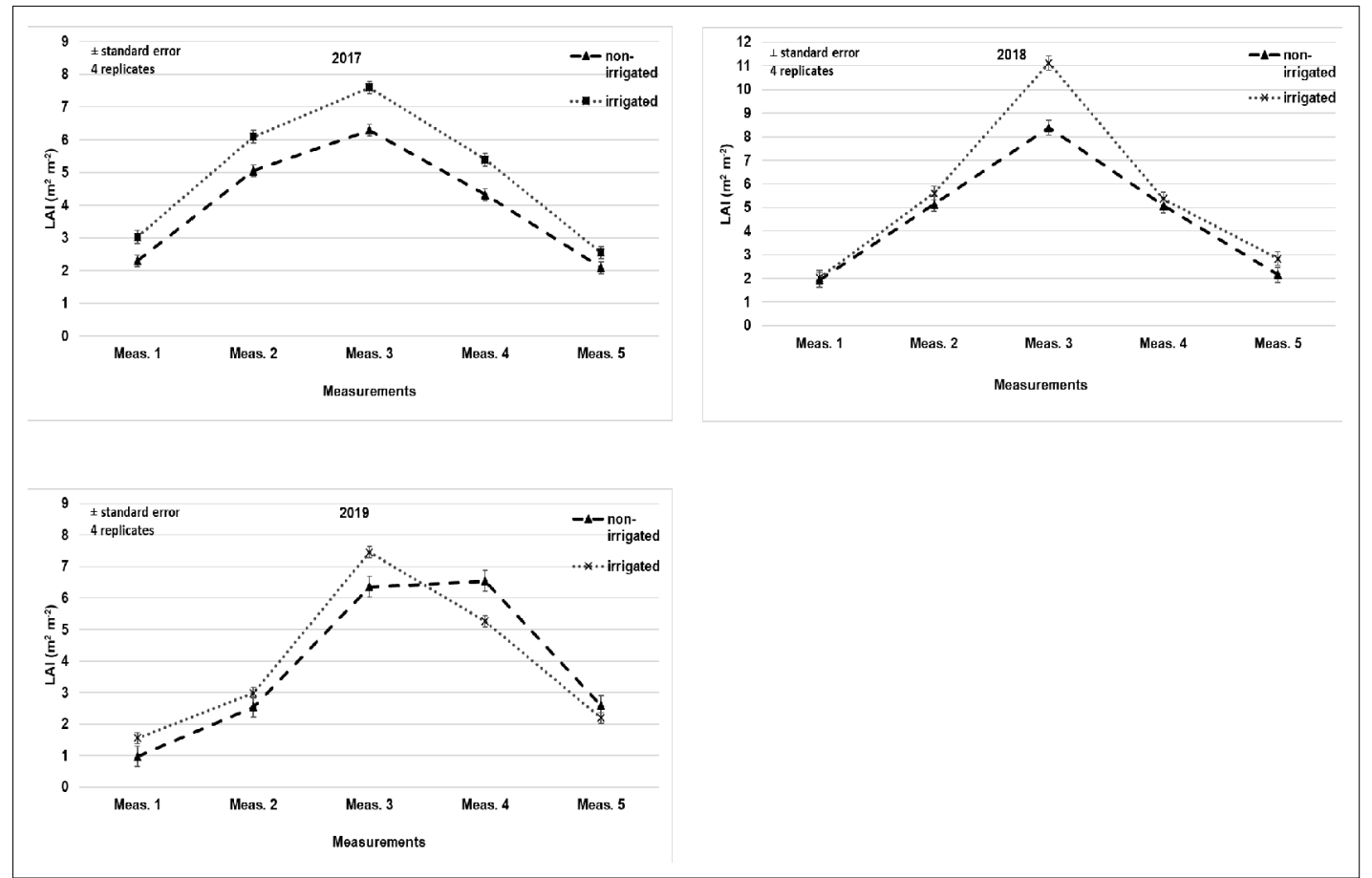

Fig 2: Effect of irrigation on the LAl of soybean genotypes in different growing seasons (2017-2019).

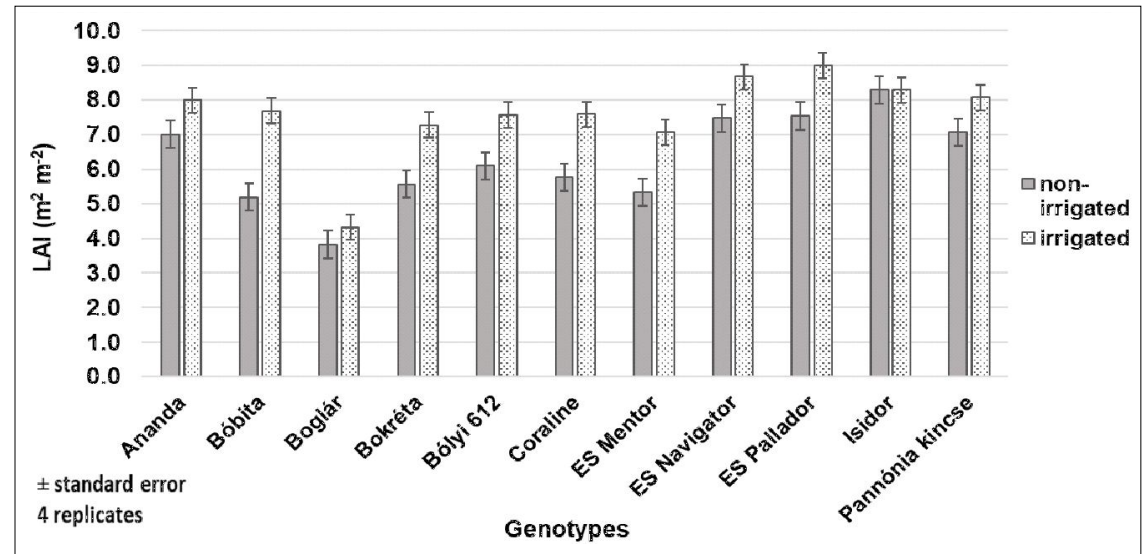

Fig 3: Effect of irrigation on the LAl of soybean genotypes (2017, Debrecen). Growth stage R6 Full seed, except Isidor and Bóbita: R5 Beginning seed. 
on average). This observation is in harmony with reports of other researchers (Maleki et al. 2013). The height of the cultivars was between $74.2 \mathrm{~cm}$ and $107.5 \mathrm{~cm}$ in $2017,74.7$ $\mathrm{cm}$ and $109.0 \mathrm{~cm}$ in 2018 and $78.4 \mathrm{~cm}$ and $99 \mathrm{~cm}$ in 2019. The average plant height of the 11 genotypes was 86.7 , 97.2 and $89.4 \mathrm{~cm}$ in 2017,2018 and 2019 , respectively.
Irrigation did not cause significant discrepancy $(p=$ 0.061 ) in the NDVI value neither in a positive nor in the negative direction (Fig 6). The average NDVI of 0.65 and 0.66 was recorded in non-irrigated plots and irrigated plots, respectively. The genotypes reaction was slightly different. The range was between 0.41 and 0.78 in the rainfed and

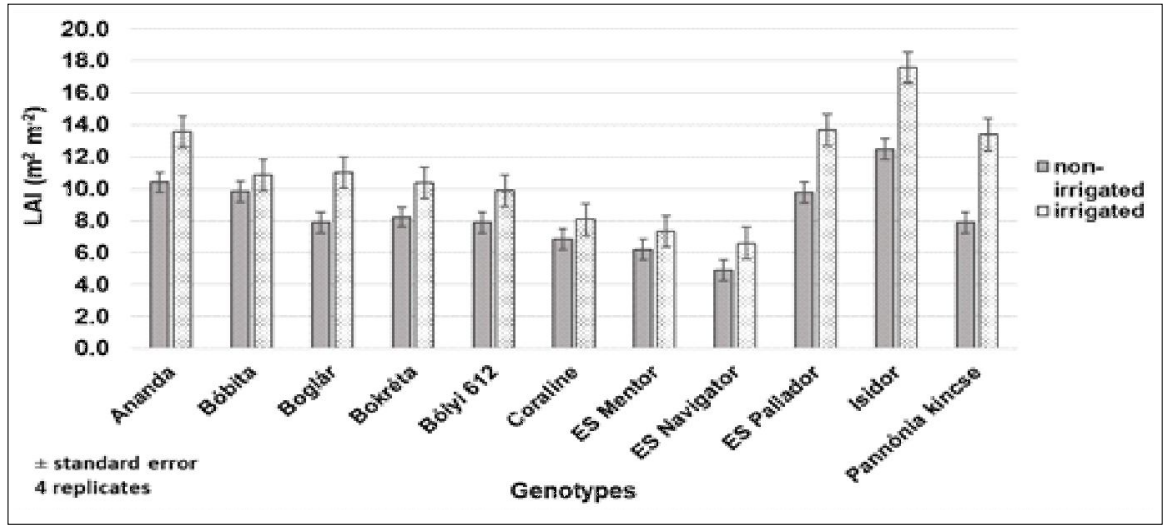

Fig 4: Effect of irrigation on the LAl of soybean genotypes (2018, Debrecen). Growth stage R4 Full pod, except ES Navigator: R5 Beginning seed.

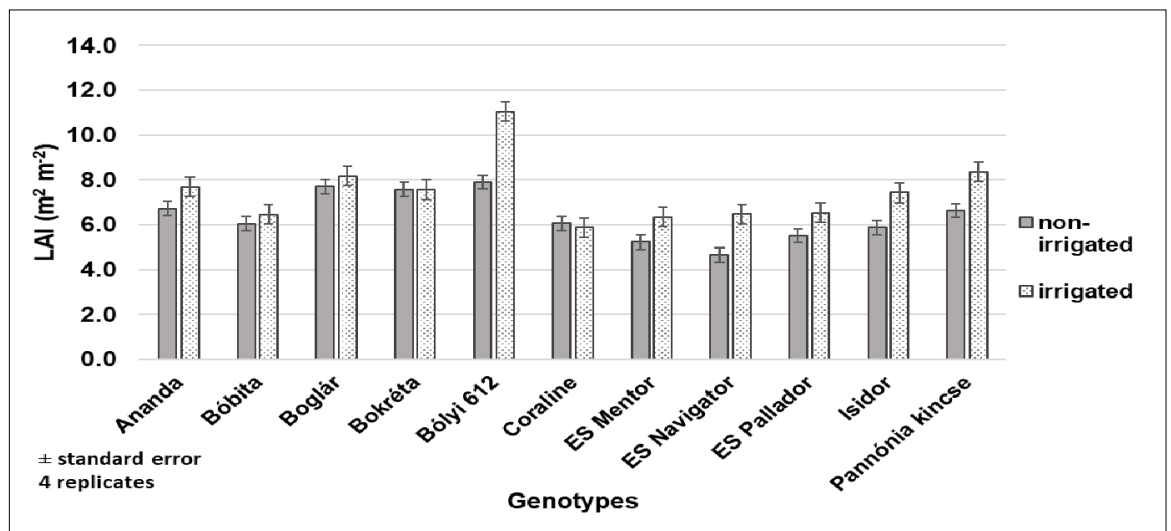

Fig 5: Effect of irrigation on the LAl of soybean genotypes (2019, Debrecen). Growth stage R4 Full pod, except ES Navigator, Boglár, ES Mentor, Bokréta: R5 Beginning seed.

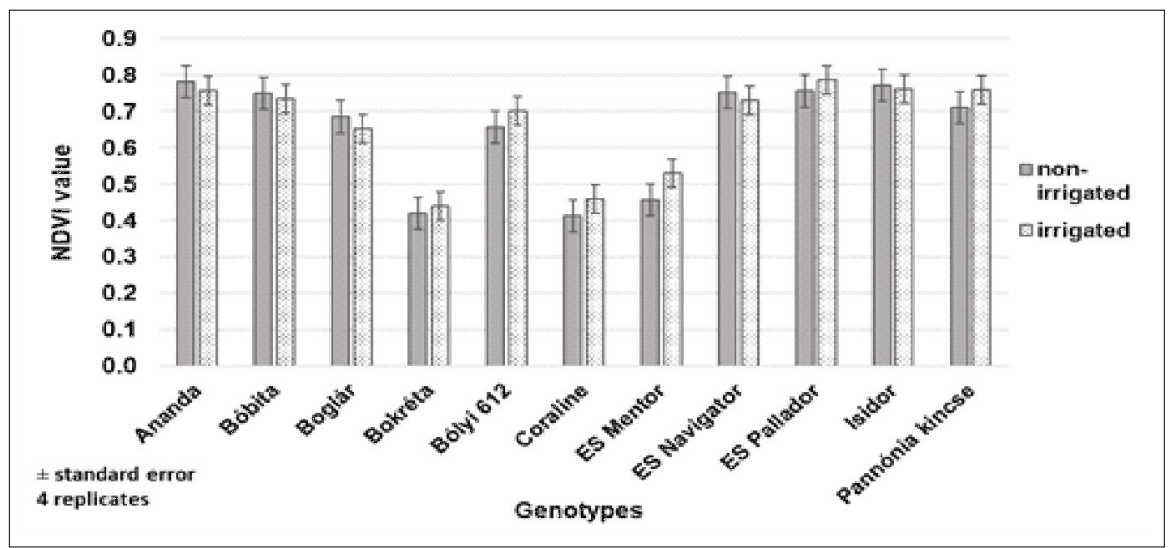

Fig 6: Effect of irrigation on the NDVI value of soybean genotypes (2017, Debrecen) Growth stage R6 Full seed, except Isidor and Bóbita: R5 Beginning seed. 
between 0.44 and 0.79 in irrigated plots in 2017. The NDVI values were higher in 2018, the average NDVI was 0.86 both in non-irrigated and irrigated plots, but the differences were also not significant $(p=0.055)$ between the irrigation treatments. The minimum value in non-irrigated plots was 0.82 (ES Navigator) and the maximum was 0.87 (ES Mentor). In irrigated plots, the minimum value was 0.85 (Bokréta) and the highest value was 0.88 (ES Pallador). In 2019, we measured similarly high values of NDVI as in 2018, the average value was 0.88 in both treatments. The irrigation did not result in significant differences $(p=0.096)$ in NDVI values. The range was between 0.86 and 0.89 in rainfed, while between 0.87 and 0.90 in irrigated plots.

These results lead us to conclude that NDVI values were not affected by the irrigation treatments in this experiment, not even in the droughty 2017 year. The highest NDVI values were measured at the R2-R3 growth stage in 2017 and 2018 and the R4-R5 stage in 2019 (Fig 7). The irrigation increased the NDVI value of the cultivars, but the differences were not significant. This observation is supported by the findings of Zhang et al. (2014).

Many researchers found a relationship between the number of nodes and the number of pods or yield in soybean plants. According to the research reports the number of nodes per plant is in close connection with the number of pods per plant or pods per hectare and yield (Egli, 2013; He et al. 2020). Our results showed a significantly higher number of nodes in the irrigated plots in 2018 (the difference was 2.8) and 2019 (the difference was 0.7).
The number of nodes was not affected significantly due to irrigation in $2017(p=0.664)$. The mean of the non-irrigated treatment was 12.7 and the irrigated was 12.9 nodes. In 2018 and 2019 irrigation caused significantly $(p<0.001$ and $\mathrm{P}=0.003$, respectively) larger number of nodes in all cultivars. The number of nodes was 13.6 in non-irrigated and 16.4 in irrigated plots in 2018. It was 13.8 in the non-irrigated and 14.5 in the irrigated plots in 2019 (Fig 8).

The effect of irrigation on the yield depends on the weather conditions, especially on the distribution and quantity of precipitation. Several researchers reported that irrigation significantly increased the yield of crops (Bellaloui and Mengistu, 2008; Montoya et al. 2017; Aydinsakir, 2018; $\mathrm{He}$ et al. 2020). The irrigation did not cause significant differences in seed yield in the average of the three years, the surplus yield due to the irrigation was only $58.24 \mathrm{~kg} \mathrm{ha}^{-1}$. The effect was significant in $2019(p<0.001)$, the irrigated plots had $453.84 \mathrm{~kg} \mathrm{ha}^{-1}$ higher yield than the non-irrigated plots.

The varieties responded differently to the irrigation in the three years (Fig 9). On average of the years, a positive response was observed in Bokréta, Bólyi 612, Coraline, ES Mentor, ES Navigator, ES Pallador and Pannónia kincse, while the irrigation caused decreasing in yield in Ananda, Bóbita, Boglár and Isidor varieties. Possibly, the surplus water application exceeded the requirements for optimum growth and production in these genotypes. Our results are consistent with other publications (Bellaloui and Mengistu, 2008; Kristó et al. 2020).

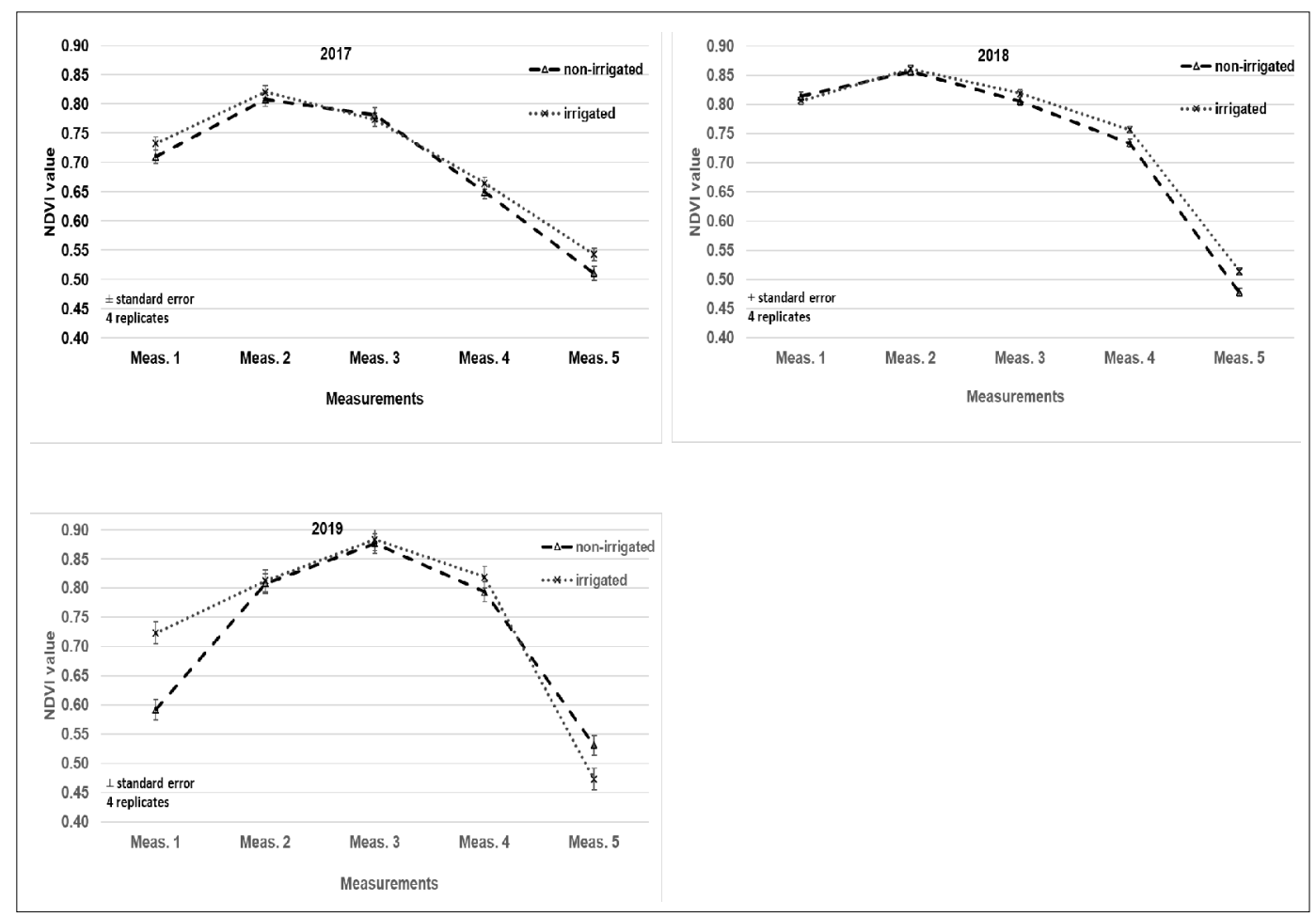

Fig 7: Effect of irrigation on the NDVI values of soybean in average of the genotypes (2017-2019). 


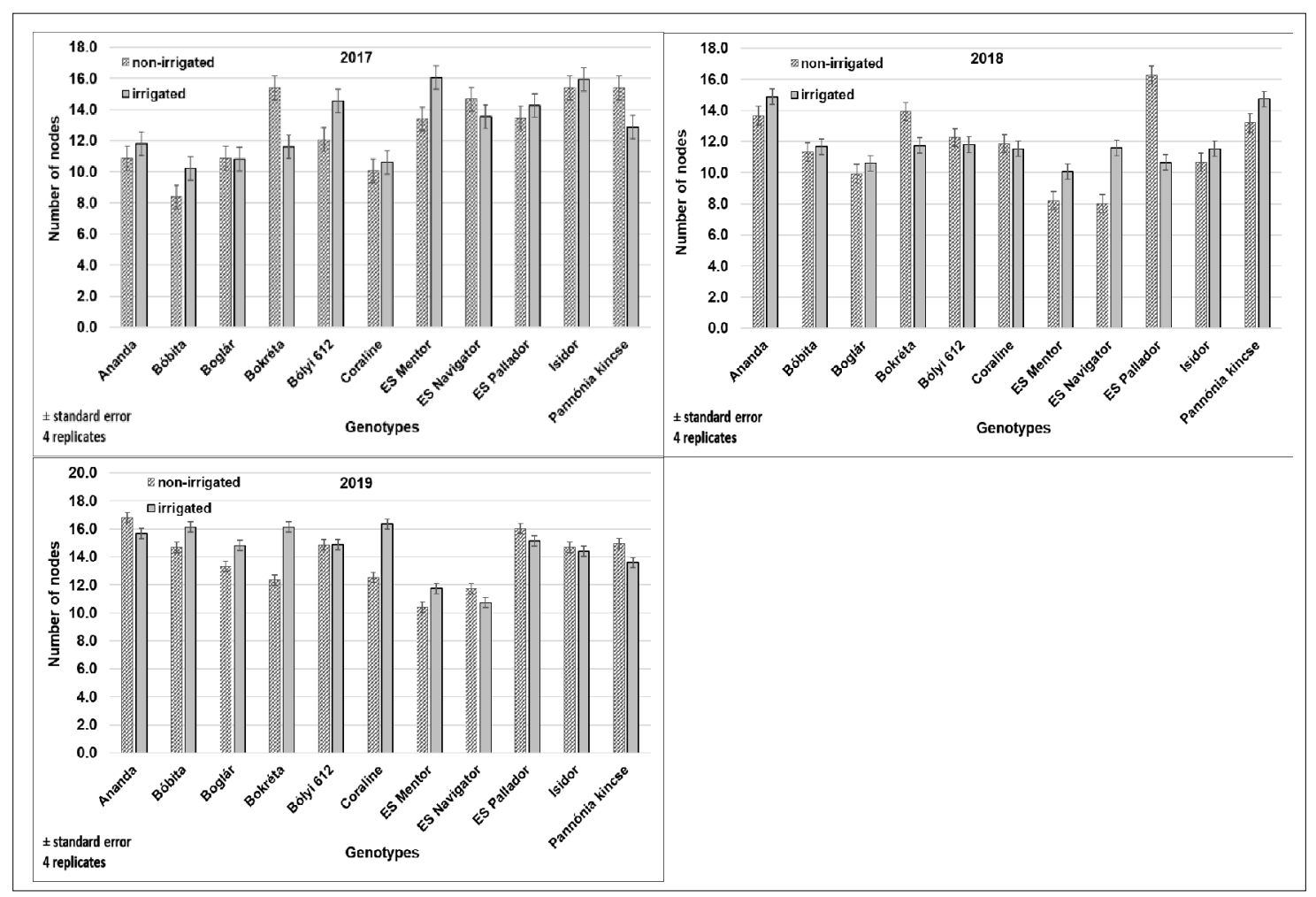

Fig 8: Effect of irrigation on the number of nodes of soybean (2017-2019).

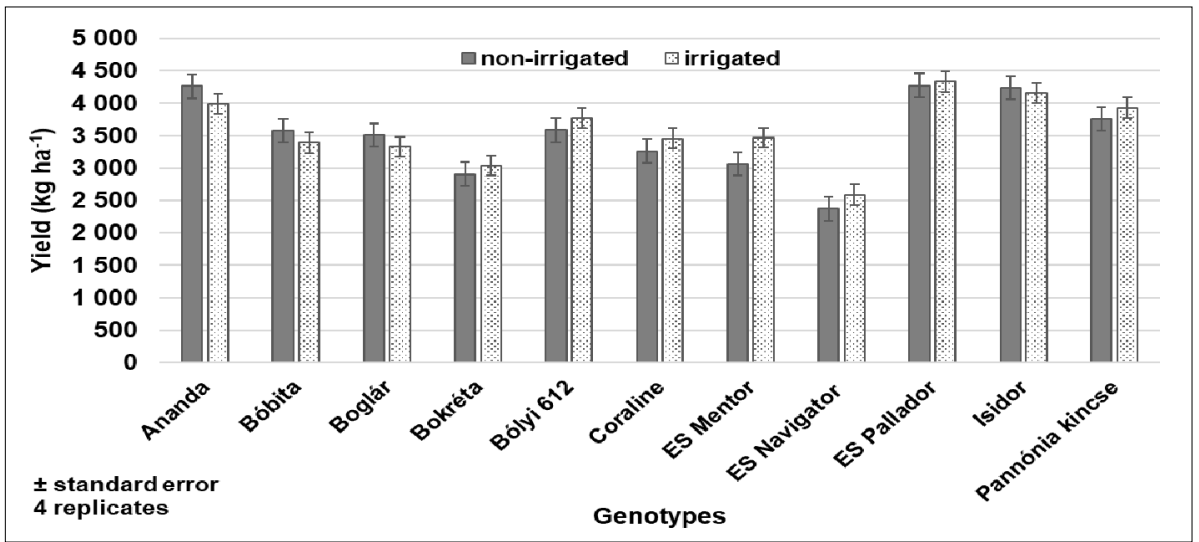

Fig 9: Effect of irrigation on the seed yield of soybean (2017-2019). Standard error of means, 4 replicates. The differences between the irrigation treatments were not significant, $p>0.05$.

The Pearson correlation analysis involving three years showed a medium correlation coefficient between the LAI and seed yield $(r=0.362$, but the correlation was significant $(p=0.003)$. This reflects the different results of other researchers (Garcia y Garcia et al. 2010; Souza et al. 2013).

Seed composition was significantly changed by the supply of water. Irrigation increased the protein content by $3.9 \%(p<0.001)$, but decreased the oil content by $-1.7 \%$ ( $p$ $=0.002$ ) in 2017. On the contrary, the data showed different results in 2018 and 2019. The irrigation treatment decreased both the protein $(-1.5 \%, p=0.038)$ and oil $(-1.8 \% p=0.042)$ content of the seeds in 2018. In 2019, the effect was not significant on the seed composition such as protein $0.4 \%$ $(p=0.493)$, oil: $0.5 \%(p=0.610)$. Partially similar observations were made by Carrera et al. (2009).

\section{CONCLUSION}

The results of our research clearly show that there are real differences among the genotypes in the measured parameters in response to irrigation. Irrigation significantly increased the number of nodes of all the tested cultivars in 2017-2019. Higher LAI values, higher plants, a higher number of nodes were observed in the irrigated plots on average of three years, but the reactions of the genotypes varied among the years. On three years average, the genotypes ES Pallador and Isidor produced the highest yield 
among the 11 tested varieties under both non-irrigated and irrigated conditions. The protein and oil content of the soybean varieties are mainly genetically regulated. There were significant differences in seed protein content among the cultivars. The protein yield was depended more on the seed yield than the protein content.

\section{Funding}

This research was funded by the EFOP-3.6.3-VEKOP-162017-00008 project. The project is co-financed by the European Union and the European Social Fund.

Conflict of interest: None.

\section{REFERENCES}

Aydinsakir, K. (2018). Yield and Quality Characteristics of Drip Irrigated Soybean under Different Irrigation Levels. Agronomy Journal. 110. 1473-1481.

Basal, O., Szabó, A. (2020). Physiology, yield and quality of soybean as affected by drought stress. Asian Journal of Agricultural Biology. 8(3): 247-252.

Bellaloui, N., Mengistu, A. (2008). Seed composition is influenced by irrigation regimes and cultivar differences in soybean. Irrigation Science. 26. 261-268.

Buezo, J., Sanz-Saez, Á., Moran, J.F., Soba, D., Aranjuelo, I., Esteban, R. (2019). Drought tolerance response of highyielding soybean varieties to mild drought: physiological and photochemical adjustments. Physiologia Plantarum. 166(1): 88-104.

Carrera, C., Martinez, M.J., Dardanelli, J., Balzarini, M. (2009). Water deficit effect on the relationship between temperature during the seed fill period and soybean seed oil and protein concentrations. Crop Science. 49: 990-998.

Dong, S., Jiang, Y., Dong, Y., Wang, L., Wang, W., Ma, Z., Yan, C., Ma, C., Liu, L. (2019). A study on soybean responses to drought stress and rehydration. Saudi Journal of Biological Sciences. 26. 2006-2017.

Du, Y., Zhao, Q., Chen, L., Yao, X., Xie, F. (2020). Effect of Drought Stress at Reproductive Stages on Growth and Nitrogen Metabolism in Soybean. Agronomy. 10(2): 302-323.

Egli, D.B. (2013). The Relationship between the Number of Nodes and Pods in Soybean Communities. Crop Science. 53(4): 1668-1676.

Garcia y Garcia, A., Persson, T., Guerra, L.C., Hoogenboom, G. (2010). Response of soybean genotypes to different irrigation regimes in a humid region of the southeastern USA. Agricultural Water Management. 97(7): 981-987.

He, J., Jin, Y., Turner, N.C., Li, F.M. (2020). Irrigation during flowering improves subsoil water uptake and grain yield in rainfed soybean. Agronomy. 10: 120.

Jaybhay, S.A., Varghese, P., Taware, S.P. (2021). Influence of foliar application of nutrient on growth, yield, economics, soil nutritional status and nutrient uptake of soybean. Legume Research. 44(11): 1322-1327.
Jha, P.K., Kumar, S.N., Ines, A.V.M. (2018). Responses of soybean to water stress and supplemental irrigation in upper IndoGangetic plain: Field experiment and modeling approach. Field Crops Research. 219: 76-86.

Kristó, I., Vályi-Nagy, M., Jakab, P., Tar, M. (2020). The effect of seed density, variety and soil inoculant on the yield of soybean. Review on Agriculture and Rural Development. 8(1-2): 91-95.

Kunert, K., Vorster, B.J. (2020). In search for drought-tolerant soybean: is the slow-wilting phenotype more than just a curiosity? Journal of Experimental Botany. 71(2): 457-460.

Licht, M., Wright, D., Lenssen, A.W. (2013). Soybean Response to Drought. Agriculture and Environment Extension Publications. 190: 1-3.

Maleki, A., Naderi, A., Naseri, R., Fathi, A., Bahamin, S., Maleki, R. (2013). Physiological Performance of Soybean Cultivars under Drought Stress. Bulletin of Environment, Pharmacology and Life Sciences. 2(6): 38-44.

Montoya, F., García, C., Pintos, F., Otero, A. (2017). Effects of irrigation regime on the growth and yield of irrigated soybean in temperate humid climatic conditions. Agricultural Water Management. 193: 30-45.

Oral, E., Tunçtürk, R., Tunçtürk, M.(2021). The Effect of Rhizobacteria in the Reducing drought Stress in Soybean (Glycine max L.). Legume Research. 44(10): 1172-1178.

Revathi, P., Arun, M.N., Sukumar, K., Dhrua,S. and Bindu, G.S.M. (2021). Enhancing the Water Stress Tolerance in Soybean (Glycine max L.) through Anti-Transpirants and Mulch. Legume Research. 44(11): 1315-1321.

Shi, A., Chen, P., Zhang, B., Hou, A. (2010). Genetic diversity and association analysis of protein and oil content in foodgrade soybeans from Asia and the United States. Plant Breeding. 129. 250-256.

Sinclair, T.R., Purcell, L.C., King, A., Sneller, C.H., Chen, P., Vadez, V. (2007). Drought tolerance and yield increase of soybean resulting from improved symbiotic $\mathrm{N}_{2}$ fixation. Field Crops Research. 101(1): 68-71.

Souza, G.M., Tiago, A.C., Suzana, C.B., Rogerio, P.S. (2013). Soybean under water deficit: physiological and yield responses. A Comprehensive Survey of International Soybean Research Genetics, Physiology, Agronomy and Nitrogen Relationships. Intech Open.

Wilson, R.F. (2004). Seed composition. In Soybeans: Improvement, Production and Uses. ASA, CSSA and SSSA: Madison, WI, USA. 621-668.

WRB. 2014. World reference base for soil resources. World Soil Resources Reports No. 106. FAO.

Wu, L., Misselbrook, T.H., Feng, L., Wu, L. (2020). Assessment of nitrogen uptake and biological nitrogen fixation responses of soybean to nitrogen fertiliser with SPACSYS. Sustainability. 12: 5921.

Zhang, Z.T., Lan, Y., Wu, P.T., Han, W.T. (2014). Model of soybean NDVI change based on time series. International Journal of Agricultural and Biological Engineering. 7(5): 64-70.

Zhao, T., Aleem, M., Sharmin, R. (2017). Adaptation to Water Stress in Soybean: Morphology to Genetics. Plant, Abiotic Stress and Responses to Climate Change. V. 33-68. 